\title{
Phylogeny of Meloidogyne spp. based on 18S rDNA and the intergenic region of mitochondrial DNA sequences
}

\author{
Myrian S. TigAno ${ }^{1, *}$, Regina M.D.G. CARnEIRo ${ }^{1}$, Ayyamperumal JeYAPRAKASH ${ }^{2}$, \\ Don W. DICKSON ${ }^{2}$ and Byron J. ADAMS ${ }^{3}$ \\ ${ }^{1}$ Embrapa Recursos Genéticos e Biotecnologia, C.P. 02372, 70849-970, Brasilia, DF, Brazil \\ ${ }^{2}$ Entomology and Nematology Department, University of Florida, Gainesville, FL 32611-0620, USA \\ ${ }^{3}$ Department of Microbiology \& Molecular Biology, Brigham Young University, Provo, UT 84602-5253, USA
}

Received: 17 January 2005; revised: 6 September 2005 Accepted for publication: 7 September 2005

\begin{abstract}
Summary - The 18S rDNA of 19 populations of Meloidogyne spp. was amplified and directly sequenced. The region of mitochondrial DNA, located in the $3^{\prime}$ portion of the gene that codes for cytochrome oxidase subunit II (COII) through a portion of the 16S rRNA (IRNA) gene, from 16 of these populations was cloned and sequenced. Heteroplasmic sequences were identified from both rDNA and mtDNA regions for several taxa. Several sequences sampled from nominal taxa differed from previously published accounts. Phylogenetic trees based on alignments of these sequences were constructed using distance, parsimony and likelihood optimality criteria. For $18 \mathrm{~S}$ rDNA data, three main clades were identified. One well supported clade (86-91\% bootstrap) included the most common and widely disseminated species, e.g., M. arenaria, M. javanica and M. incognita, some recently described or redescribed species (M. floridensis, M. paranaensis, and M. ethiopica) plus numerous unidentified isolates. All mitotic parthenogenetic species, except for $M$. oryzae, were included in this clade. Other, less well supported clades included the amphimictic and facultative meiotic species M. hapla, M. microtyla, M. maritima and M. duytsi. One such clade comprised three meiotic parthenogens (M. exigua, M. graminicola and M. chitwoodi) and $M$. oryzae. This clade was moderately supported (77\% bootstrap) but the relationships within this clade were poor. For mitochondrial DNA data, only the species in clade I from rDNA analysis, and $M$. hapla were analysed. These species formed a well supported clade (100\% bootstrap) to the exclusion of M. mayaguensis and M. hapla. The addition of taxa and mtDNA data to publicly available records improved the discrimination sensitivity of species and atypical, non-identified, isolates.
\end{abstract}

Keywords - molecular biology, molecular diagnosis, root-knot nematodes.

Root-knot nematodes (RKN) of the genus Meloidogyne Goeldi, 1892 comprise more than 80 species. Many of them are important pathogens of numerous agricultural crops grown in tropical, subtropical and moderate temperate regions. The most common species, Meloidogyne arenaria (Neal, 1889) Chitwood, 1949, M. incognita (Kofoid \& White, 1919) Chitwood, 1949 and M. javanica (Treub, 1885) Chitwood, 1949 are extremely polyphagous, with up to 3000 plant species listed as hosts (Trudgill \& Blok, 2001). There is great diversity present among these species, not only regarding their host range, but also relative to their cytogenetics (varying levels of aneuploidy and polyploidy), and their mode of reproduction (varying from obligatory amphimixis to mitotic parthenogenesis) (Triantaphyllou, 1985). Identification of species is based primarily on morphological features of females, males and second-stage juveniles (Eisenback \& Triantaphyllou, 1991), as esterase and malate dehydrogenase isozyme profiles derived from single females by PAGE (Esbenshade \& Triantaphyllou, 1985; Carneiro et al., 2000). However, precise and reliable identification based on morphological characters is a difficult task even for qualified taxonomists with expertise in the genus. Enzymatic profiles have been designated for only about 26 species, and since these can only be determined for females, the most common developmental stage, second-stage juveniles, cannot be identified by this method (Carneiro et al., 2000).

The Polymerase Chain Reaction (PCR) amplification and digestion of amplified product with restriction endonucleases of the region located in the $3^{\prime}$ portion of the mitochondrial gene that codes for cytochrome oxi-

\footnotetext{
*Corresponding author, e-mail: myrian@ cenargen.embrapa.br
} 
dase subunit II (COII) through a portion of the 16S rRNA (IRNA) gene allowed discrimination of five major Meloidogyne spp. (Powers \& Harris, 1993). Subsequently, the sequence of this region was used to confirm the identification of M. mayaguensis Rammah \& Hirschmann, 1988 populations (Blok et al., 2002; Brito et al., 2004).

Much previous phylogenetic inference in Meloidogyne has been carried out. Based on cytogenetic information, Triantaphyllou (1985) made the assumption that mitotic parthenogens evolved from meiotic parthenogenetic ancestors, following suppression of meiotic process and establishing various levels of ploidy. Other phylogenetic studies, which were based on protein and DNA analysis, showed a strong relationship among ameiotic species. (Dickson et al., 1971; Dalmasso \& Bergé, 1978; Esbenshade \& Triantaphyllou, 1987; Castagnone-Sereno et al., 1993; Baum et al., 1994; Van der Beek et al., 1998). Recently, a phylogeny was predicated on small subunit $18 \mathrm{~S}$ rDNA sequences of 12 species of Meloidogyne (De Ley et al., 2002) and for five species using over 47 genes (Scholl et al., 2005). The study of De Ley et al. (2002) supported close relationships between the three major ameiotic species, M. arenaria, M. javanica and $M$. incognita. Again, these mitotic parthenogens were clearly different from either the meiotic or obligatory amphimictic species. The major contribution of the Scholl and Bird (2005) analysis was the elucidation of relationships among three mitotic parthenogens that had heretofore been poorly documented.

In the present study, 19 populations of Meloidogyne were analysed based on 18S rDNA sequences, and 16 of these were also analysed based on mitochondrial DNA sequences. Within these populations, five were unidentified and some were from different geographical regions than previously reported. For example, M. mayaguensis was detected for the first time in Brazil and the USA (Carneiro et al., 2001; Brito et al., 2004), and M. ethiopica Whitehead, 1968 was found for the first time in Brazil and Chile (Carneiro et al., 2003, 2004a). Meloidogyne floridensis Handoo, Nyczepir, Esmenjaud, van der Beek, Castagnone-Sereno, Carta, Skantar \& Higgins, 2004 is a recently described species from Florida, USA. The unidentified population Meloidogyne sp. (isolate 38) was detected in Brazil from yakon plants (Polymnia sonchifolia) and presented an atypical esterase phenotype Y3 (Carneiro et al., 2000). The unidentified populations designated MS3 and MS1 are both from the same geographical region of El Salvador and are important pathogens of coffee in that country (Carneiro et al., 2004b).

\section{Materials and methods}

\section{POPULATIONS AND DNA EXTRACTION}

Nineteen populations (13 collected in Brazil) were sampled for 18S DNA sequencing (Table 1). Sixteen of these populations were also used in the analysis of the mitochondrial DNA sequence. The latter analysis did not include M. exigua Goeldi, 1887, M. oryzae Maas, Sanders $\&$ Dede, 1978 and the semaphoronts of Meloidogyne sp. (isolates 35,47 ) were reduced to isolate 35 .

From each population, an isolate was cultured starting from the progeny of a single female. Identification of most taxa was based on isozyme phenotypes, resolved by PAGE from young, egg-laying females (Carneiro et al., 2000, 2004a). Genomic DNA was extracted from 200-300 $\mu 1$ of eggs (Randig et al., 2002).

\section{AMPLIFICATION OF 18S RNA GENE BY PCR}

The 18S rDNA was partially amplified using two sets of primers: 1A (forward) and 3B (reverse; Baldwin et al., 1997), and two primers specially designed for this study: MelF (forward) and MelR (reverse) (Table 2). A $50 \mu \mathrm{l}$ reaction was used containing $5.0 \mu \mathrm{l}$ of $10 \times$ reaction buffer, $1.5 \mathrm{mM} \mathrm{MgCl}_{2}, 0.2 \mathrm{mM}$ dNTPs, $2 \mathrm{pM}$ of forward and reverse primers of each set, $1.25 \mathrm{U}$ of Taq polymerase (CLP, San Diego, CA, USA) and $2 \mu \mathrm{l}$ of genomic DNA. DNA was amplified using the PTC100 Thermocycler (MJ Research, Inc., Waltham, MA, USA), under the following cycling parameters: 1 cycle at $94^{\circ} \mathrm{C}$ for $7 \mathrm{~min}$ followed by 35 cycles at $94^{\circ} \mathrm{C}$ for $1 \mathrm{~min}, 50^{\circ} \mathrm{C}$ for $1 \mathrm{~min}$, and $72^{\circ} \mathrm{C}$ for $1 \mathrm{~min}$. The last step was $72^{\circ} \mathrm{C}$ for $10 \mathrm{~min}$. PCR products were purified with a QIAquick PCR purification kit (Qiagen Inc., Santa Clara, CA, USA).

\section{MitOCHONDRIAL DNA AMPLIFICATION BY PCR}

Primers C2F3 5'-GGTCAATGTTCAGAAATTTGTGG-3' and 1108 5'-TACCTTTGACCAATCACGCT-3" (Powers \& Harris, 1993) were used to amplify the mitochondrial region located between the $3^{\prime}$ portion of cytochrome oxidase subunit II (COII) gene and the $5^{\prime}$ portion of 16S rRNA (lRNA) gene. Long PCR or 'high fidelity' PCR (Barnes, 1994; Jeyaprakash \& Hoy, 2000) was performed in a $50 \mu \mathrm{l}$ volume containing $50 \mathrm{mM}$ Tris (pH 9.2), $16 \mathrm{mM}$ ammonium sulphate, $1.75 \mathrm{mM} \mathrm{MgCl}_{2}$, $350 \mu \mathrm{M}$ dNTPs, $400 \mathrm{pM}$ of primers, $3 \mu \mathrm{l}$ of DNA, $0.2 \mathrm{U}$ 
Table 1. Meloidogyne species/isolates, esterase phenotypes, origins, original host plants, source of species or isolate and the mtDNA region size.

\begin{tabular}{|c|c|c|c|c|c|}
\hline Species (isolate) & $\begin{array}{l}\text { Esterase } \\
\text { phenotype }\end{array}$ & Origin & Host plant & $\begin{array}{l}\text { Source of } \\
\text { material }\end{array}$ & $\begin{array}{l}\text { MtDNA region } \\
\text { size (bp) }\end{array}$ \\
\hline M. arabicida & $\begin{array}{l}\text { AR2 (Carneiro et al., } \\
\text { 2004) }\end{array}$ & Costa Rica & Coffea arabica $\mathrm{L}$. & $\begin{array}{l}\text { P. Topard, Cirad, } \\
\text { Costa Rica }\end{array}$ & $1683-1684$ \\
\hline M. arenaria $(36)$ & $\begin{array}{l}\text { A3 (Carneiro, pers. } \\
\text { obs.) }\end{array}$ & Petrolina/PE, Brazil & $\begin{array}{l}\text { Lycopersicon } \\
\text { esculentum Mill. cv. } \\
\text { Moneymaker }\end{array}$ & $\begin{array}{l}\text { W. Moreira, Embrapa, } \\
\text { Petrolina, PE, Brazil }\end{array}$ & 1112 \\
\hline M. ethiopica & $\begin{array}{l}\text { E3 (Carneiro et al., } \\
\text { 2004) }\end{array}$ & $\begin{array}{l}\text { Encruzilhada/RS, } \\
\text { Brazil }\end{array}$ & $\begin{array}{l}\text { Actinidia deliciosa } \\
\text { (A. Chev) }\end{array}$ & $\begin{array}{l}\text { R.M.V. Sanhueza, } \\
\text { Embrapa, Bento } \\
\text { Gonçalves, RS, Brazil }\end{array}$ & 1639 \\
\hline M. exigua (17) & $\begin{array}{l}\text { E1 (Carneiro et al., } \\
\text { 2000) }\end{array}$ & Lavras/MG, Brazil & Coffea arabica $\mathrm{L}$. & $\begin{array}{l}\text { V.P. Campos, UFLA, } \\
\text { Lavras, MG, Brazil }\end{array}$ & Not analysed \\
\hline M. floridensis & $\begin{array}{l}\text { Fl3 (Carneiro et al., } \\
\text { 2000) }\end{array}$ & Florida, USA & $\begin{array}{l}\text { Prunus persica }(\mathrm{L} .) \\
\text { Batsch }\end{array}$ & $\begin{array}{l}\text { A.P. Nyczepir, USDA- } \\
\text { ARS, SE Fruit \& Tree } \\
\text { Nut Research Lab, } \\
\text { Byron, GA, USA }\end{array}$ & 1111 \\
\hline M. hapla (19) & $\begin{array}{l}\text { H1 (Carneiro et al., } \\
\text { 2000) }\end{array}$ & Farropilha/RS, Brazil & Actinidia deliciosa & $\begin{array}{l}\text { C.B. Gomes, Embrapa, } \\
\text { Pelotas, RS., Brazil }\end{array}$ & 528 \\
\hline M. incognita (10) & $\begin{array}{l}\text { I1 (Carneiro et al., } \\
\text { 2000) }\end{array}$ & Londrina/PR, Brazil & Coffea arabica $\mathrm{L}$. & $\begin{array}{l}\text { R.G. Carneiro, IAPAR, } \\
\text { Londrina, PR, Brazil }\end{array}$ & 1502 \\
\hline M. javanica (13) & $\begin{array}{l}\text { J3 (Carneiro et al., } \\
2000)\end{array}$ & Londrina/PR, Brazil & Glycine max Merr. & $\begin{array}{l}\text { J.F. Veloso, Embrapa, } \\
\text { Londrina, PR, Brazil }\end{array}$ & 1640 \\
\hline M. mayaguensis & $\begin{array}{l}\text { M2 (Carneiro et al., } \\
\text { 2003) }\end{array}$ & Petrolina/PE, Brazil & Psidium guajava $\mathrm{L}$. & $\begin{array}{l}\text { W. Moreira, Embrapa, } \\
\text { Petrolina, PE, Brazil }\end{array}$ & 705 \\
\hline M. morocciensis & $\begin{array}{l}\text { A3 (Rammah \& } \\
\text { Hirschmann, 2003) }\end{array}$ & Morocco & $\begin{array}{l}\text { Prunus persica (L.) } \\
\text { Batsch }\end{array}$ & $\begin{array}{l}\text { G. Karssen, Plant } \\
\text { Protection Service, } \\
\text { Wageningen, } \\
\text { The Netherlands }\end{array}$ & 1112 \\
\hline M. oryzae & $\begin{array}{l}\text { O1 (Carneiro et al., } \\
\text { 2000) }\end{array}$ & Surinam & Oryza sativa $\mathrm{L}$. & $\begin{array}{l}\text { P. Quénéhervé, IRD, } \\
\text { Fort de France, } \\
\text { Martinique }\end{array}$ & Not analysed \\
\hline M. paranaensis & $\begin{array}{l}\text { P1 (Carneiro et al., } \\
\text { 2000) }\end{array}$ & Pompeia/SP, Brazil & Coffea arabica & $\begin{array}{l}\text { W. Gonçalves, IAC, } \\
\text { Campinas, SP, Brazil }\end{array}$ & 1255 \\
\hline $\begin{array}{l}\text { Meloidogyne sp. } \\
\quad(35)\end{array}$ & $\begin{array}{l}\text { S1 (Castro et al., } \\
\text { 2003) }\end{array}$ & Diorama/GO, Brazil & Glycine $\max$ & $\begin{array}{l}\text { J.M.C. Castro, UFV, } \\
\text { Viçosa, MG, Brazil }\end{array}$ & 1514 \\
\hline $\begin{array}{l}\text { Meloidogyne sp. } \\
\quad(47)\end{array}$ & $\begin{array}{l}\text { S1 (Cofcewciz et al., } \\
\text { 2004) }\end{array}$ & Cajati/SP, Brazil & Musa spp. & $\begin{array}{l}\text { E. Cofcewciz, UFEPEL, } \\
\text { Pelotas, RS, Brazil }\end{array}$ & Not analysed \\
\hline $\begin{array}{l}\text { Meloidogyne sp. } \\
\quad \text { (MS1) }\end{array}$ & $\begin{array}{l}\text { SA2 (Carneiro et al., } \\
\text { 2004) }\end{array}$ & El Salvador & Coffea arabica & $\begin{array}{l}\text { J.-L. Sarah, Cirad-Amis, } \\
\text { Montpellier, France }\end{array}$ & 1656 \\
\hline $\begin{array}{l}\text { Meloidogyne sp. } \\
\quad \text { (MS3) }\end{array}$ & $\begin{array}{l}\text { SA4 (Carneiro et al., } \\
\text { 2004) }\end{array}$ & El Salvador & Coffea arabica & $\begin{array}{l}\text { J.-L. Sarah, Cirad-Amis, } \\
\text { Montpellier, France }\end{array}$ & 1656 \\
\hline $\begin{array}{l}\text { Meloidogyne sp. } \\
\quad(38)\end{array}$ & $\begin{array}{l}\text { Y3 (Carneiro et al., } \\
\text { 2000) }\end{array}$ & $\begin{array}{l}\text { Capão Bonito/SP, } \\
\text { Brazil }\end{array}$ & $\begin{array}{l}\text { Polymnia sonchifolia } \\
\text { Poepp. }\end{array}$ & $\begin{array}{l}\text { M. Mendes, UNESP- } \\
\text { Botucatu, SP, Brazil }\end{array}$ & 1639 \\
\hline $\begin{array}{l}\text { Meloidogyne sp. } \\
\quad(40)\end{array}$ & G3 (this study) & Brasilia/DF, Brazil & $\begin{array}{l}\text { Pfaffia glomerata } \\
\text { (Spreng.) }\end{array}$ & $\begin{array}{l}\text { V. Gonzaga, Embrapa, } \\
\text { Brasília, DF, Brazil }\end{array}$ & $1626-1627$ \\
\hline $\begin{array}{l}\text { Meloidogyne sp. } \\
\quad(50)\end{array}$ & $\begin{array}{l}\text { L3 (Carneiro et al., } \\
\text { 2000) }\end{array}$ & $\begin{array}{l}\text { Caxias do Sul/RS, } \\
\text { Brazil }\end{array}$ & $\begin{array}{l}\text { Lavandula spica } \\
\text { Loisel. }\end{array}$ & $\begin{array}{l}\text { C.B. Gomes, Embrapa, } \\
\text { Pelotas, RS, Brazil }\end{array}$ & 1641 \\
\hline
\end{tabular}


M.S. Tigano et al.

Table 2. List of amplification and sequencing primers used in the $18 S$ rDNA analyses.

\begin{tabular}{|c|c|c|}
\hline Primer & Sequence & $\begin{array}{c}\text { Location based on } \\
\text { Meloidogyne arenaria } \mathrm{U} 42342\end{array}$ \\
\hline $1 \mathrm{~A}$ & 5'-GGCGATCGAAAAGATTAAGCC-3' & $779-790$ \\
\hline $3 \mathrm{~B}$ & 5'-GGCGATCGATTGGCAAATGCTTTCGC-3' & 1668-1684 (Reverse) \\
\hline MelF & 5'-TACGGACTGAGATAATGGT-3' & $1574-1592$ \\
\hline MelR & $5^{\prime}$-GGTTCAAGCCACTGCGA-3' & 2459-2475 (Reverse) \\
\hline
\end{tabular}

of Tgo DNA polymerase (Roche Applied Science, Indianapolis, IN, USA) and $5 \mathrm{U}$ of Taq DNA polymerase (Roche Applied Science).

Amplification was carried out using a linked profile consisting of three different cycles: $i$ ) one cycle consisting of denaturation at $94^{\circ} \mathrm{C}$ for $2 \mathrm{~min}$; $\mathrm{ii}$ ) ten cycles consisting of denaturation at $94^{\circ} \mathrm{C}$ for $10 \mathrm{~s}$, annealing at $48^{\circ} \mathrm{C}$ for $30 \mathrm{~s}$ and extension at $68^{\circ} \mathrm{C}$ for $2 \mathrm{~min}$; and iii) 25 cycles consisting of denaturation at $94^{\circ} \mathrm{C}$ for $10 \mathrm{~s}$, annealing at $48^{\circ} \mathrm{C}$ for $30 \mathrm{~s}$ and extension at $68^{\circ} \mathrm{C}$ for 2 min plus $20 \mathrm{~s}$ added for every consecutive cycle. Electrophoresis was performed on a $1 \%$ TAE agarose gel to detect and inspect the amplified DNA product.

\section{DNA SEQUENCING}

The mitochondrial DNA PCR products were cloned into plasmid pCR2.1-TOPO using a procedure and reagents provided by the manufacturer (Invitrogen, Carlsbad, CA, USA). Purified PCR products of $18 \mathrm{~S}$ rDNA and clones of mitochondrial DNA were sequenced, in both strands, using an ABI PRISM ${ }^{\mathrm{TM}}$ Dye Terminator Cycling Sequencing Ready Reaction Kit (Perkin-Elmer Corp., Foster City, CA, USA). The primers used for the direct sequencing of $18 \mathrm{~S}$ rDNA were the same used for amplification. Sequences were assembled using Sequencher 4.1 (Genes Codes Corp., Ann Arbor, MI, USA). At least two clones of each isolate were sequenced.

\section{SEQUENCE ALIGNMENTS}

All sequences obtained in this study were aligned using the default parameters of Clustal X v. 1.83 (Thompson et al., 1997) and adjusted in MacClade 4.02 (Sinauer Associates, Inc., Sunderland, MA, USA). The sequences of 18S RNA gene were aligned against the alignment produced by De Ley et al. (2002) and available in GenBank (NCBI REF 1107784) using the profile alignment mode in Clustal X. In the final dataset, sequences were reduced by $31 \mathrm{bp}$ characters downstream of $5^{\prime}$ of $1 \mathrm{~A}$ primer, and $100 \mathrm{bp}$ upstream of $3^{\prime}$ MelR primer, in order to adjust our sequences to the GenBank-downloaded sequences that were shorter.

\section{Phylogenetic ANALYSES}

Models of sequence evolution were evaluated using ModelTest 3.06 (Posada \& Crandall, 1998). For the rDNA sequences dataset, ModelTest favoured the TrNef $+\mathrm{I}+\mathrm{G}$ model, by Hierarchical Likelihood Ratio Tests (hLRTs) and the GTR $+\mathrm{I}+\mathrm{G}$ model, by Akaike Information Criterion (AIC), with a 0.6633 and 0.6488 gamma distribution shaped parameter. For the mtDNA sequences dataset, both hLRTs and AIC tests, favoured the Hasegawa-KishinoYano $(\mathrm{HKY}+\mathrm{G})$ model (Hasegawa et al., 1985), with a 0.1674 gamma distribution shaped parameter.

Phylogenetic relationships were reconstructed using distance-based (neighbour-joining, NJ; Saitou \& Nei, 1987), and discrete character-based (maximum parsimony and maximum likelihood, respectively MP and ML) algorithms using PAUP* m4.0v10 (Swofford, 2002). Maximum parsimony heuristic searches were performed twice, once with 3000 bootstrap replicates, using the fast default settings, and once without bootstrapping, using more exhaustive settings (100 replicates of random branch addition). A neighbour-joining tree employing the BioNJ option was obtained using the Log Determinant distance measure to account for possible positional rate heterogeneity artefacts (Steel et al., 2000), and subjected to 3000 bootstrap replications. Optimal models of sequence substitution as determined by Akaike and likelihood ratio tests (Posada \& Buckley, 2004) were used for maximum likelihood searches, conducted heuristically with 100 replicates of random branch addition. The trees were compared statistically using the Kishino-Hasegawa and Shimodaira-Hasegawa pairwise tests. Gaps were treated as missing data for most of the analyses, except for MP with the mtDNA dataset where gaps were also treated as 5th state, considering that in this dataset gaps occurred in conserved blocks and could be inferred positionally with 
greater confidence. In the case of the rDNA dataset, Subanguina radicicola (Greef, 1872) Paramonov, 1967 was used as the outgroup taxon, as suggested by De Ley et al. (2002). For the mtDNA dataset, phylogenetic trees were rooted with $M$. hapla Chitwood, 1949.

A partition-homogeneity test was carried out to explore the combinability of the rDNA and mtDNA datasets, as among the different gene regions of the mtDNA dataset.

\section{Results}

\section{RDNA SEQUENCES}

The nearly complete $18 \mathrm{~S}$ rDNA sequences obtained from the 19 taxa varied from 1111 (M. floridensis) to 1714 (M. incognita) bp. Sequences were deposited in GenBank (Table 3) and the aligned data matrix is available from the corresponding author.

Identical rDNA sequences were obtained for M. floridensis and the two unidentified populations, Meloidogyne sp. (isolates 35, 47); thus only the sequence of $M$. floridensis was used for further analyses. The same occurred

Table 3. List of GenBank accession numbers for the material studied.

\begin{tabular}{lcc}
\hline Species (isolate) & 18S rDNA & mtDNA region \\
\hline M. arabicida & AY942625 & AY942852 \\
M. arenaria (36) & AY942623 & AY635610 \\
M. ethiopica & AY942630 & AY942848 \\
M. exigua (17) & AY942627 & - \\
M. floridensis & AY942621 & AY635609 \\
M. hapla (19) & AY942628 & AY942850 \\
M. incognita (10) & AY942624 & AY635611 \\
M. javanica (13) & AY942626 & AY635612 \\
M. mayaguensis & AY942629 & AY635613 \\
M. morocciensis & AY942632 & AY942849 \\
M. oryzae & AY942631 & - \\
M. paranaensis & AY942622 & AY942851 \\
Meloidogyne sp. (35) & - & AY942853 \\
Meloidogyne sp. (47) & - & - \\
Meloidogyne sp. (MS1) & - & AY942854 \\
Meloidogyne sp. (MS3) & AY942636 & AY942855 \\
Meloidogyne sp. (38) & AY942633 & AY942856 \\
Meloidogyne sp. (40) & AY942634 & AY942857 \\
Meloidogyne sp. (50) & AY942635 & AY942858 \\
\hline
\end{tabular}

\footnotetext{
${ }^{1}$ Identical sequences were obtained for Meloidogyne sp. isolates 35 and 47 and M. floridensis; also for Meloidogyne sp. isolates MS1 and MS3.

${ }^{2}$ Sequences not analysed for M. exigua, M. oryzae and Meloidogyne sp. isolate 47.
}

with the two unidentified populations from El Salvador, Meloidogyne sp. (isolates MS1, MS3). In this case, only the sequence of MS3 was used. A total of 16 sequences were aligned to the previously published alignment (De Ley et al., 2002). The final alignment contained 1623 positions with 369 variable characters, 227 of which were phylogenetically informative characters under parsimony analysis. A+T content ranged from 49 to $53 \%$ in the sequences analysed.

Our populations of M. arenaria, M. incognita, M. javanica, M. exigua and $M$. hapla did not give identical $18 \mathrm{~S}$ rDNA sequences that corresponded with the published sequences for the same species (De Ley et al., 2002). Between the two sequences from $M$. arenaria (present study vs accession number AF535867), the differences were related to two substitutions, being one with ambiguity, and four insertions, of which two were an unknown nucleotide $(\mathrm{N})$. The two $M$. incognita isolates (present study $v s$ accession number AF535868) presented one insertion and ten substitution differences between them. The sequence for M. javanica previously reported (accession number AF442193), and the one used in the present study differed by 24 nucleotide substitutions, 18 ambiguities, and four insertions. The two M. exigua isolates (present study $v s$ accession number AF442200) differed by 16 nucleotide substitutions and four insertions. Finally, the two sequences obtained for M. hapla differed by two insertions involving unidentified nucleotides $(\mathrm{N})$ in the published sequence (accession number AF442194).

The pairwise distances among the Meloidogyne spp. $18 \mathrm{~S}$ rDNA sequences is shown in Table 4, differences between species varying from 0 to $151 \mathrm{bp}$. The absence of difference among taxa is due to the fact that some sequences presented character ambiguity, which is not counted by the distance analysis.

The topology of the ML trees obtained with the two models favoured by ModelTest, $\operatorname{TrNef}+\mathrm{I}+\mathrm{G}$ and $\mathrm{GTR}+\mathrm{I}+\mathrm{G}$, was consistent, except for the position of M. mayaguensis. This species appears as a sister taxon to M. ethiopica and Meloidogyne sp. (isolate 38) in the model $\operatorname{TrNef}+\mathrm{I}+\mathrm{G}$, whereas in the model $\mathrm{GTR}+\mathrm{I}+\mathrm{G}$ it stood separately from the other species. The pairwise tests showed no statistically difference between the topologies of the two ML trees. The topology of ML tree using the model GTR $+\mathrm{I}+\mathrm{G}$ and $\mathrm{NJ}$ and MP trees were congruent, represented by the ML tree, with bootstrap values obtained via MP and NJ in Figure 1. The tree is divided artificially into three clades for ease of discussion. 


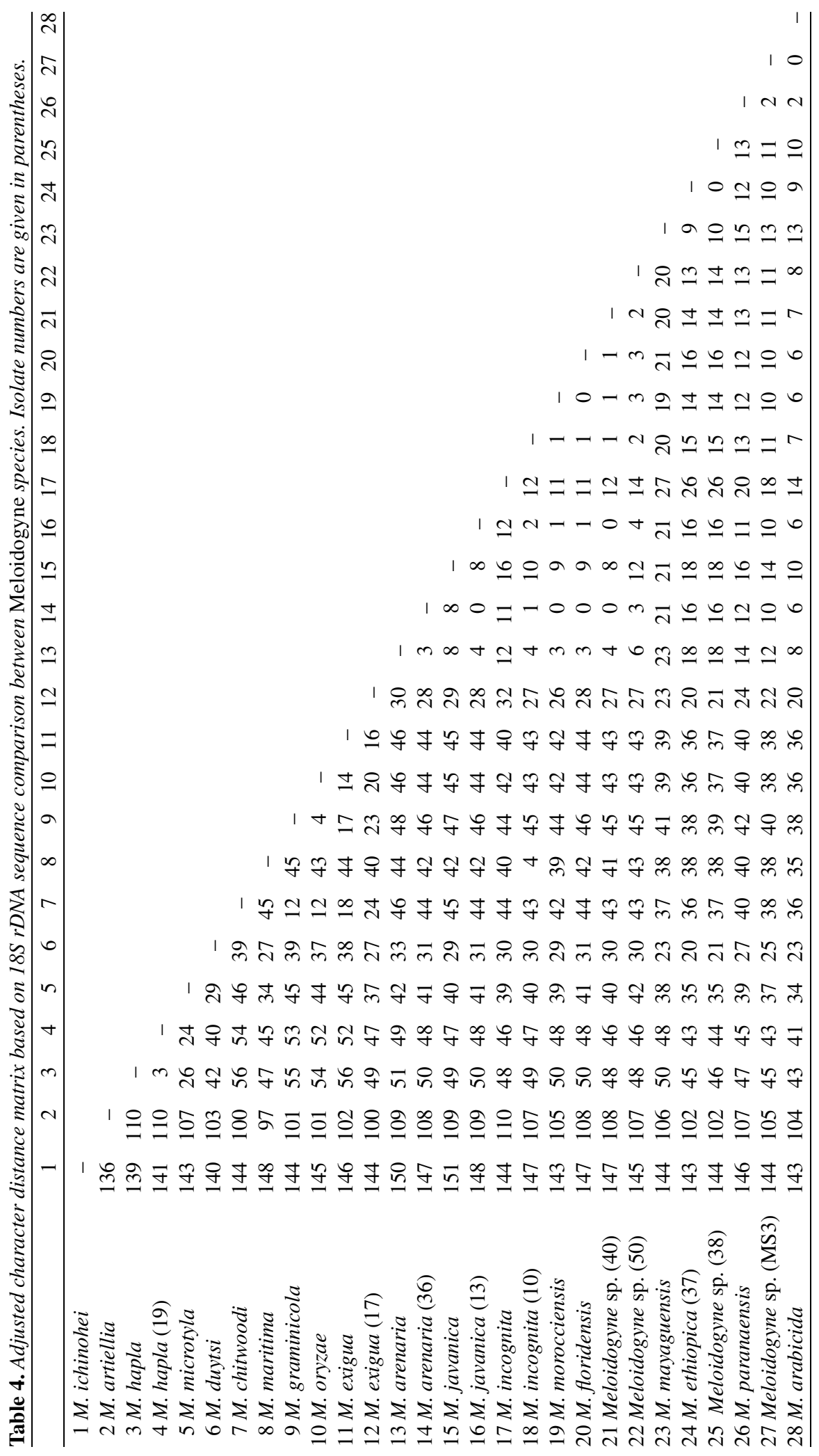




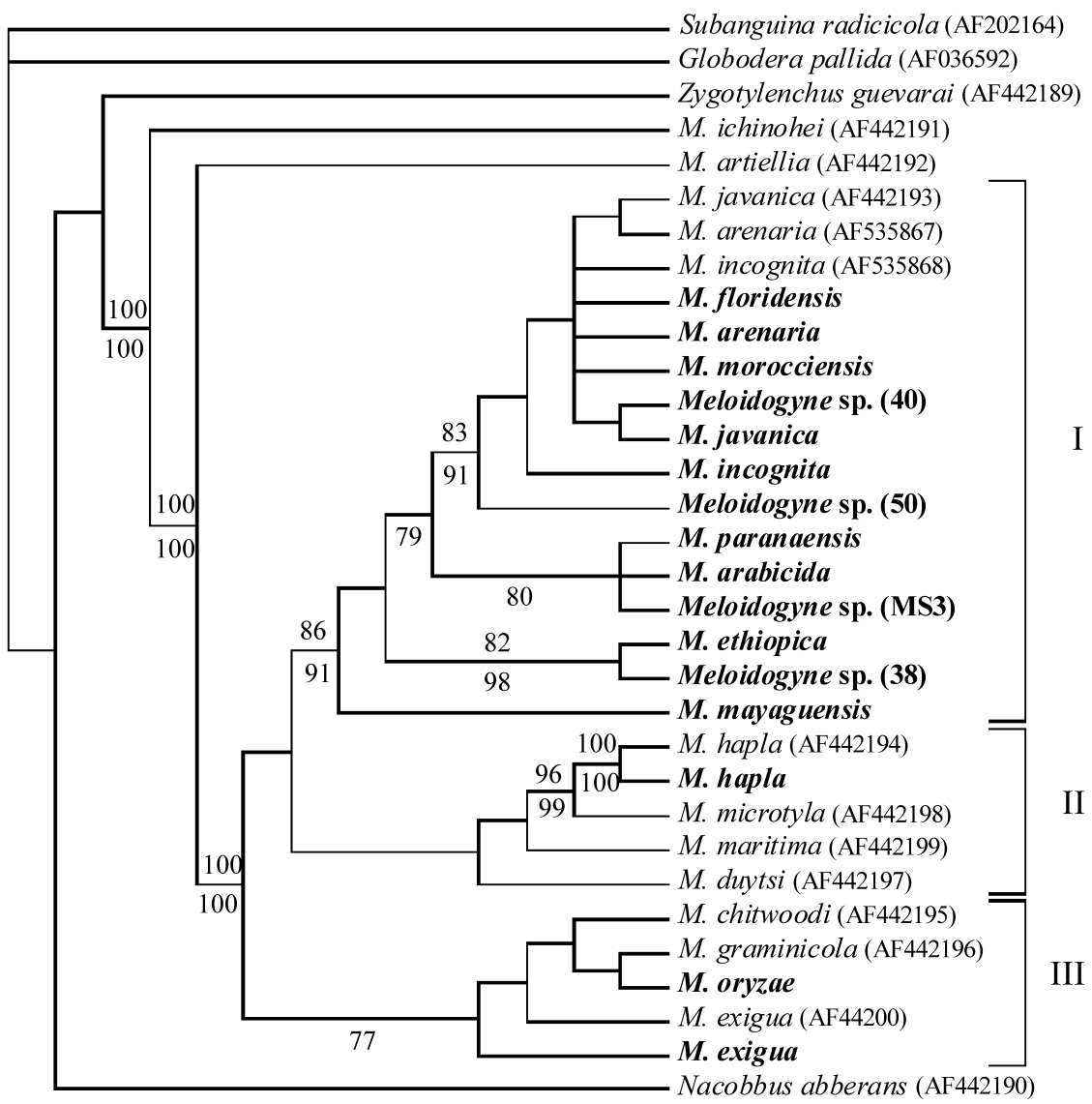

Fig. 1. Maximum likelihood tree based on $18 S$ rRNA gene sequences. Identical rDNA sequences were obtained for Meloidogyne floridensis and the two Meloidogyne sp. (isolates 35 and 37), so only the sequence of $\mathrm{M}$. floridensis was used in the analyses. The same occurred with the two unidentified populations from El Salvador, Meloidogyne sp. (MS1 and MS3). In this case, only the sequence of MS3 was used. The accession numbers of the GenBank-downloaded sequences are show in parentheses. Numbers next to branches are bootstrap values (>70\%) from MP analysis (above) and NJ analysis (below). Isolates unique to this study are shown in bold. Monophyletic groups (I, II, III) are arbitrarily delimited and presented for ease of discussion only.

Our populations of $M$. arenaria, M. incognita, M. javanica, $M$. exigua and $M$. hapla did not give identical sequences to the published sequences for the same species (De Ley et al., 2002). The recently described M. floridensis and $M$. morocciensis Rammah \& Hirschmann, 1990 were sister taxa to $M$. arenaria, M. incognita and M. javanica, and also to the unidentified populations of Meloidogyne sp. (isolates 35, 37, 40, 50). Relationships among these species cannot be resolved unambiguously as they share few synapomorphies among their subtle differences (Table 4), but together they comprise a robust clade (83-91\% bootstrap support; Fig. 1). The unidentified populations, Meloidogyne sp. (isolates MS1, MS3), which have identical sequences, form a fairly robust clade with M. paranaensis Carneiro, Carneiro, Abrantes, San- tos \& Almeida, 1996 and M. arabicida López \& Salazar, 1989 (80\% bootstrap support; 0-2 bp differences). Meloidogyne ethiopica and Meloidogyne sp. (isolate 38) were sister taxa in another subgroup (82-98\% bootstrap support) of clade I. Meloidogyne mayaguensis is depicted as a sister taxon to the remaining taxa in clade I, maintaining the greatest number of changes (19-27 bp) relative to the other isolates in clade I (Table 4). Clade II was not supported, except for the two isolates of M. hapla and their sister taxon relationship to M. microtyla (96-99\% bootstrap support), M. duytsi Karssen, Aelst \& Van der Putten, 1998 and M. maritima Jepson, 1987, all of which are also depicted as members of clade II. Support for this relationship is poor. Meloidogyne oryzae, M. graminicola Golden \& Birchfield, 1965, M. chitwoodi Golden, 
O'Bannon, Santo \& Finley, 1980 and M. exigua comprise a clade (clade III; $77 \%$ bootstrap support), but relationships within this clade are not supported by bootstrap analyses. The M. exigua isolates were paraphyletic.

\section{MitochONDRIAL DNA SEQUENCES}

The size of the amplified PCR products for the mitochondrial region spanning portions of COII through IRNA genes, determined by the sequence without the sequence of the primers, varied from 528 to $1684 \mathrm{bp}$ for M. hapla and $M$. arabicida, respectively (Table 1). Sequences were deposited in GenBank (Table 3). This region included partial COII and 16S rRNA sequences, the complete tRNAHis sequence and AT-rich region sequences, located between the COII and tRNA-His genes, and varied in length. AT-rich regions were completely absent in M. hapla sequences, which has been shown previously (Hugall et al., 1997). The Brazilian M. hapla isolate produced the smallest product, as previously reported for other isolates of this species (Powers \& Harris, 1993; Blok et al., 2002). Also, the Brazilian population of $M$. mayaguensis produced a 705 bp product, which was in agreement with the size previously reported for this species (Blok et al., 2002). Isolates of M. arenaria and M. morocciensis produced fragments of the same size (1112 bp). The same occurred with $M$. ethiopica and the unidentified isolate, $M e$ loidogyne sp. (isolate 38 ), which produced a PCR product of $1639 \mathrm{bp}$, and the unidentified populations from El Sal- vador, MS1 and MS3, each with 1656 bp products. The M. floridensis and M. paranaensis isolates produced products of 1110 and $1255 \mathrm{bp}$, respectively, which is similar in size to M. arenaria and M. morocciensis. Meloidogyne sp. (isolate 35) and $M$. incognita isolates produced products of 1514 and $1502 \mathrm{bp}$, respectively. Meloidogyne incognita has been reported as having populations that produce two sizes of PCR product of $c a 1500$ and 1700 bp (Powers \& Harris, 1993; Blok et al., 2002). The M. javanica isolate produced a product with a smaller size of $1640 \mathrm{bp}$ than obtained from another isolate of the same species with 1700 bp (Powers \& Harris, 1993; Blok et al., 2002).

We detected clone sequence polymorphisms for most of the species, except $M$. paranaensis, M. javanica, M. arenaria, M. hapla and Meloidogyne sp. (isolate 38). The maximum sequence divergence among clones of the same isolate was only $0.3 \%$ and, upon phylogenetic analyses, all intraspecific polymorphic clones were more closely related to each other than to a clone from any other taxon in the analysis. Thus, only one sequence (clone) from each isolate was used for subsequent analyses. The final alignment contained 1890 positions with 53 phylogenetically informative characters for parsimony analyses. A+T content ranged from 84 to $88 \%$ in the sequences analysed. Distances among the Meloidogyne spp. mtDNA sequences is shown in Table 5, and the differences between species varied from 1 bp between M. ethiopica and Meloidogyne sp. (isolate 38), and the two

Table 5. Adjusted character distance matrix based on mtDNA sequence comparison between Meloidogyne species. Isolate numbers are given in parentheses.

\begin{tabular}{|c|c|c|c|c|c|c|c|c|c|c|c|c|c|c|c|c|}
\hline & 1 & 2 & 3 & 4 & 5 & 6 & 7 & 8 & 9 & 10 & 11 & 12 & 13 & 14 & 15 & 16 \\
\hline $1 \mathrm{M}$. morocciensis & - & & & & & & & & & & & & & & & \\
\hline $2 M$. arenaria & 2 & - & & & & & & & & & & & & & & \\
\hline 3 M. javanica & 4 & 4 & - & & & & & & & & & & & & & \\
\hline 4 Meloidogyne sp. (40) & 5 & 5 & 10 & - & & & & & & & & & & & & \\
\hline $5 \mathrm{M}$. ethiopica & 6 & 6 & 9 & 9 & - & & & & & & & & & & & \\
\hline 6 Meloidogyne sp. (38) & 7 & 7 & 10 & 10 & 1 & - & & & & & & & & & & \\
\hline 7 Meloidogyne sp. (50) & 7 & 7 & 13 & 13 & 3 & 4 & - & & & & & & & & & \\
\hline $8 \mathrm{M}$. floridensis & 7 & 7 & 7 & 7 & 5 & 6 & 6 & - & & & & & & & & \\
\hline 9 Meloidogyne sp. (35) & 16 & 15 & 22 & 22 & 18 & 18 & 22 & 12 & - & & & & & & & \\
\hline 10 M. incognita & 10 & 10 & 16 & 16 & 12 & 13 & 16 & 7 & 10 & - & & & & & & \\
\hline 11 Meloidogyne sp. (MS3) & 7 & 7 & 15 & 13 & 12 & 13 & 16 & 5 & 23 & 17 & - & & & & & \\
\hline 12 Meloidogyne sp. (MS1) & 7 & 7 & 16 & 14 & 13 & 14 & 17 & 6 & 24 & 18 & 1 & - & & & & \\
\hline 13 M. paranaensis & 9 & 9 & 13 & 14 & 11 & 11 & 12 & 9 & 22 & 13 & 13 & 14 & - & & & \\
\hline 14 M. arabicida & 12 & 12 & 29 & 29 & 26 & 27 & 30 & 10 & 34 & 29 & 28 & 29 & 13 & - & & \\
\hline 15 M. mayaguensis & 60 & 59 & 60 & 60 & 57 & 57 & 59 & 60 & 59 & 59 & 59 & 59 & 58 & 58 & - & \\
\hline 16 M. hapla & 104 & 104 & 105 & 103 & 102 & 102 & 103 & 105 & 104 & 104 & 102 & 102 & 103 & 102 & 98 & \\
\hline
\end{tabular}


unidentified isolates MS1 and MS3, to 105 bp between $M$. hapla and M. javanica, and between M. hapla and M. floridensis (Table 5).

The partition-homogeneity among the genes and intergenic regions on mitochondrial DNA sequences showed that the genes and intergenic region were probably all inherited together, and all share a common evolutionary history, so in the further analyses all sequence will be used.

The MP (gaps treated as missing data), NJ and ML trees were congruent, and are represented here by the parsimony tree. Bootstrap values obtained with MP and $\mathrm{NJ}$ are shown in Figure 2. All the species grouped in clade I from the rDNA analysis (Fig. 1) formed a wellsupported clade (100\% bootstrap) to the exclusion of $M$. mayaguensis and M. hapla. Both species were the most divergent from other species with 57-105 bp differences (Table 5). In this clade, some sister taxa, identified in the $18 \mathrm{~S}$ analysis, were observed. The unidentified isolates Meloidogyne sp. (MS1 and MS3), M. incognita and the unidentified isolate Meloidogyne sp. (isolate 35), and M. ethiopica and the unidentified isolates Meloidogyne sp.

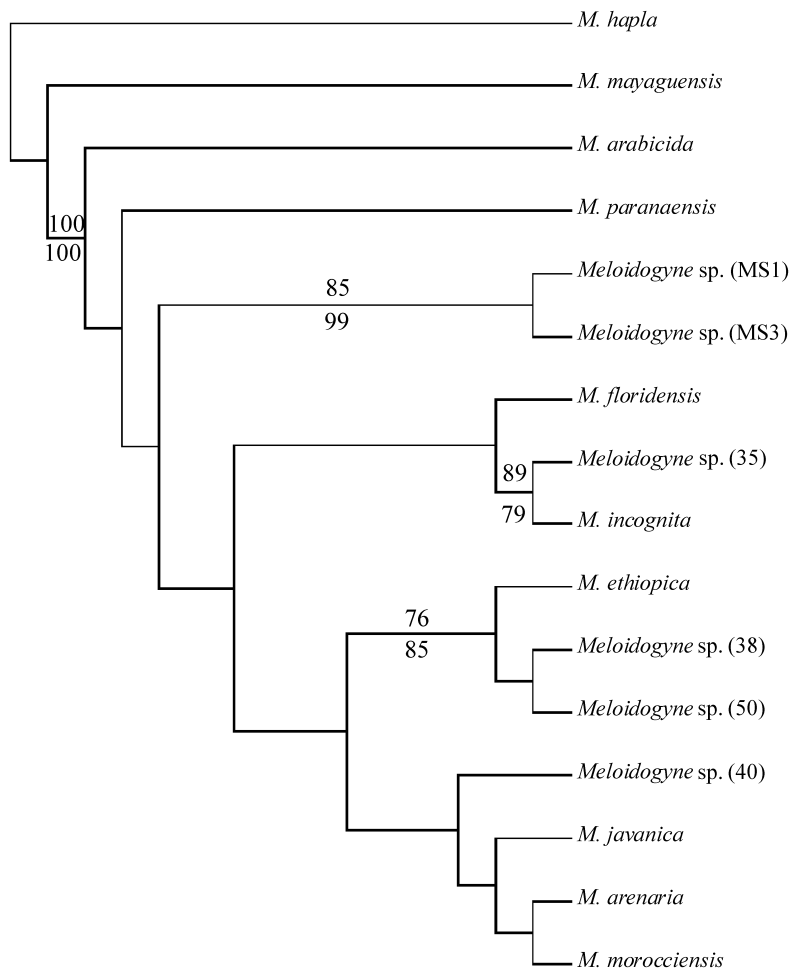

Fig. 2. Maximum parsimony tree based on mtDNA sequences. Numbers next to branches are bootstrap values from MP analysis (above) and NJ analysis (below). (isolates 38, 50), each appeared well-supported as sister taxa.

For the isolates sampled for both $18 \mathrm{~S}$ rDNA and mtDNA, the dataset failed a homogeneity partition test, which suggest that these two regions have different evolutionary history $(P \leqslant 0.01)$ and should not be combined for phylogenetic analysis.

\section{Discussion}

Our results using $18 \mathrm{~S}$ rDNA sequences for phylogenetic analyses were consistent with the results obtained by De Ley et al. (2002). Interestingly, several of the sequences from the same species (as deposited in public databases) were not identical to those we isolated, identified and sequenced. This implies that these species are more molecularly heterogenous than previously thought. Clearly, greater effort needs to be directed to more extensive and intensive sampling of populations in order to improve the likelihood that intraspecific and phylogenetic variation is accurately partitioned.

We report the same three main clades as observed by De Ley et al. (2002). In our study, several species and unidentified isolates were included in clade I. With the introduction of new species or isolates, three subgroups were identified in this clade. In the previous study (De Ley et al., 2002), clade I included the mitotic parthenogens, namely, $M$. arenaria, $M$. incognita and $M$. javanica. In this study we were able to include other mitotic parthenogenetic species: M. mayaguensis, M. morocciensis, M. paranaensis and $M$. ethiopica. These taxa are shown to be members of clade I, which includes the supposedly mitotic parthenogen $M$. arabicida. The mode of reproduction for $M$. arabicida was not given in species description, but was later reported to have $c a 30$ chromosomes and to reproduce by mitotic parthenogenesis (Hernandez, 1997). Clade I also included all unidentified species that we subjected to analyses. Their mode of reproduction has not yet been studied. In the case of Meloidogyne sp. (isolates 35, 37 , their esterase profiles are the same as other unidentified populations detected in USA that have 35 chromosomes (S1 M1 = Br2) (Carneiro et al., 2004b), and reproduce by mitotic parthenogenesis (Esbenshade \& Triantaphyllou, 1985). The mode of reproduction of the species in this clade is probably by obligatory mitotic parthenogenesis, except for $M$. floridensis which was described as showing evidence for a meiotic parthenogenetic pathway (Handoo et al., 2004). Also, another probable mitotic parthenogen, $M$. oryzae, was not included in clade I. 
Meloidogyne oryzae was described as having $2 \mathrm{n}=52$ 54 chromosomes (Esbenshade \& Triantaphyllou, 1985), which indicates that this species probably reproduces by obligatory mitotic triploid parthenogenesis. This species is a member of clade III, which includes the three meiotic pathogens (M. graminicola, M. chitwoodi and M. exigua). In this clade, M. oryzae and $M$. graminicola are sister taxa. Both of these species are important in rice plantations, and were included in the morphological graminis-group because they have similar morphological characters, e.g., the second-stage juvenile tail tapering to a long narrow hyaline portion and marked clavate terminus. Qualitative differences between $M$. oryzae and $M$. graminicola are small and the species are not easily separated by morphology alone (Jepson, 1987). The isolates of M. arenaria and $M$. morocciensis produced amplified $18 \mathrm{~S}$ fragments of the same size (1112 bp). They are very similar in morphology, and have the same esterase phenotype (A3; Cliff \& Hirschmann, 1985; Rammah \& Hirschmann, 1990). Meloidogyne incognita and the unidentified isolates Meloidogyne sp. (isolates 35, 37), also produced similar PCR products and recent studies showed they clustered together in PCR-RAPD with $100 \%$ of bootstrap support (Cofcewicz et al., 2004). This suggests that these two species diverged recently.

Clear separation of the ameiotic species from other species has been shown in previous phylogenetic studies (Esbenshade \& Triantaphyllou, 1987; Castagnone-Sereno et al., 1993; Van der Beek et al., 1998; De Ley et al., 2002; Castillo et al., 2003). The mode of reproduction from the M. hapla isolate used in this study was not determined, but De Ley et al. (2002) have showed that both meiotic and mitotic isolates of $M$. hapla had identical 18S DNA sequences. Our results, in general, agree with the previous assumptions that the evolution in Meloidogyne is related to the mode of reproduction (Triantaphyllou, 1985). However, if the mode of reproduction is confirmed for the species analysed, character mapping suggests that mitotic parthenogenesis in the genus may have multiple origins.

In order to understand more fully the relationships among the species in clade I, we have also subjected them to analyses based on the mtDNA region between the COII and IRNA genes. This region has been used for diagnostics of Meloidogyne spp. (Powers \& Harris, 1993; Blok et al., 2002; Brito et al., 2004). Phylogenetic analysis of the complete region, including partial COII and partial IRNA sequences, the complete sequence for tRNA-His and the AT rich region, produced one strongly supported clade. All the species that appear in clade I of the rDNA analyses were from a similar clade in the mtDNA analysis with the exception of $M$. mayaguensis. Although this species was included in clade I, it stood apart from the others. The size of the PCR product obtained with the COII/lRNA mtDNA primers ( $c a 700 \mathrm{bp}$ ), distinguishes $M$. mayaguensis from the other widespread species with mitotic parthenogenetic reproduction. Some sister taxa identified by mtDNA analysis are discordant from the rDNA results. The unidentified isolate, Meloidogyne sp. (isolate 50) was showed to be in the same subgroup of the common root-knot nematodes, M. arenaria, $M$. javanica and $M$. incognita, based on the rDNA phylogenetic trees (83-91 bs). However, in the mtDNA phylogenetic trees, this isolate appeared as a sister taxon to the unidentified Meloidogyne sp. (isolate 38) and M. ethiopica (76-85 bootstrap support). Also, M. arenaria, M. javanica, M. morocciensis and Meloidogyne sp. (isolate 40), were closer to M. ethiopica and Meloidogyne sp. (isolates 38, 50) than to M. floridensis, M. incognita and Meloidogyne sp. (isolate 35). Clade membership between $M$. incognita, $M$. javanica and $M$. arenaria were resolved, but not supported. However, the mtDNA phylogenetic trees are concordant with those obtained by PCR-RAPD analyses (Randig et al., 2002; Carneiro et al., 2004b). Meloidogyne arabicida, M. paranaensis and the unidentified isolates, Meloidogyne sp. (isolates MS1 and MS3), were shown to be sister taxa in the rDNA trees $(80 \%$ bs $)$, but in the mtDNA trees they were not resolved. Although, these three species are different morphologically and have different esterase phenotypes, they are all pathogens of coffee in Central America (Carneiro et al., 2004b). Regarding the unidentified isolates from El Salvador, they appear to be very closely related. They were identical for $18 \mathrm{~S}$ rRNA sequence and presented only $1 \mathrm{bp}$ difference in their mtDNA sequence. These two isolates clustered together with $100 \%$ bootstrap support in PCR-RAPD studies, and they are probably a recent genetic divergence of the same new species (Carneiro et al., 2004b). The same was observed for Meloidogyne sp. (isolate 38) and M. ethiopica, but these two species are very different in PCR-RAPD studies (Randig et al., 2002) and morphology (data not included). High levels of nucleotide sequence identity in the 18S rRNA gene are commonly found among species of other genera, such as Caenorhabditis and Heterorhabditis, suggesting that these species may have diverged from each other recently (Fitch et al., 1995; Liu et al., 1997). Considering both regions analysed, Meloidogyne sp. (isolate 40) appeared to be more closely related to $M$. arenaria, M. morocciensis and $M$. javanica than to the other 
species studied. The relationship of Meloidogyne sp. (isolate 50) and the other species analysed was discordant between the 18S rDNA and mtDNA datasets. Detailed morphological analyses aimed at clarifying the relationship among these atypical isolates and nominal species are currently underway.

The rDNA and mtDNA tree topologies revealed phylogenetic discordance among several lineages and, as interpreted by the homogeneity partition test, likely reflect different evolutionary histories. The phylogenetic utility of both molecular markers is frustrated by taxon sampling, the information content of mtDNA and rDNA regions and cytonuclear genomic dissociation. However, the addition of taxa and mtDNA data to publicly available $18 \mathrm{~S}$ rDNA records improved the discrimination sensitivity of species and atypical unidentified isolates, and highlighted several instances of diagnostic and taxonomic discord.

\section{Acknowledgements}

The authors wish to thank CAPES and EMBRAPA for financial support to M.S. Tigano and acknowledge the help received from Khuong Nguyen, Ugur Gozel, Martin Garcia-Varela and Maria L. Mendes. We are especially grateful to I. De Ley for candid discussions on this topic and for sharing unpublished sequence data and alignments.

\section{References}

Baldwin, J.G., Frisse, L.M., Vida, J.T., Eddleman, C.D. \& ThomAs, W.K. (1997). An evolutionary framework for the study of developmental evolution in a set of nematodes related to Caenorhabditis elegans. Molecular Phylogenetics and Evolution 8, 249-259.

BARNES, W. (1994). PCR amplification of up to 35-kb DNA with high fidelity and high yield from $\lambda$ bacteriophage templates. Proceedings of the National Academy of Science, USA 91, 2216-2220.

BAum, T.J., Gresshoff, P.M., Lewis, S.A. \& DeAn, R.A. (1994). Characterization and phylogenetic analysis of four root-knot nematode species using DNA amplification fingerprinting and automated polyacrylamide gel electrophoresis. Molecular Plant-Microbe Interactions 7, 39-47.

Blok, V.C., Wishart, J., Fargette, M., Berthier, K. \& PHILlips, M.S. (2002). Mitochondrial DNA differences distinguishing Meloidogyne mayaguensis from the major species of tropical root-knot nematodes. Nematology 4, 773781.
Brito, J.A., Powers, T.O., Mullin, P.G., Inserra, R.N. \& DiCKSON, D.W. (2004). Morphological and molecular characterization of Meloidogyne mayaguensis isolates from Florida. Journal of Nematology 36, 232-240.

CARneIRo, R.M.D.G., AlmeidA, M.R.A. \& QuÉNhÉRVÉ, P. (2000). Enzyme phenotype of Meloidogyne spp. populations. Nematology 2, 645-654.

CARneiro, R.M.D.G., Moreira, W.A., Moreira, A., AlmeidA, M.R.A. \& Gomes, A.C.M.M. (2001). Primeiro registro de Meloidogyne mayaguensis em goiabeira no Brasil. Nematologia Brasileira 25, 223-228.

Carneiro, R.M.D.G., Gomes, C.B., Almeida, M.R.A., Gomes, A.C.M.M. \& MARTins, I. (2003). Primeiro registro de Meloidogyne ethiopica Whitehead, 1968, em plantas de quivi no Brasil e reação de diferentes plantas hospedeiras. Nematologia Brasileira 27, 151-158.

CARneiro, R.M.D.G., Almeida, M.R.A. \& Gomes, A.C.M.M. (2004a). Additional information on Meloidogyne ethiopica Whitehead, 1968 a root-knot nematode parasitizing kiwi and grape-vine from Brazil and Chile. Nematology 6, 109-123.

CARneIRo, R.M.D.G., Tigano, M.S., RANDig, O., ALMEIDA, M.R.A. \& SARAH, J.-L. (2004b). Identification and genetic diversity of Meloidogyne spp. (Tylenchida: Meloidogynidae) on coffee from Brazil, Central America and Hawaii. Nematology 6, 287-298.

Castagnone-Sereno, P., Piotte, C., Uijthof, J., Abad, P., Wajnberg, E., VAndlerberghe Masutti, F. BonGiovanni, M. \& Dalmasso, A. (1993). Phylogenetic relationships between amphimictic and parthenogenetic nematodes of the genus Meloidogyne as inferred from repetitive DNA analysis. Heredity 70, 195-204.

Castillo, P., Vovlas, N., Subbotin, S. \& Troccoli, A. (2003). A new root-knot nematode, Meloidogyne baetica n. sp. (Nematoda: Heteroderidae), parasitizing wild olive in southern Spain. Phytopathology 93, 1093-1102.

Cliff, G.M. \& Hirschmann, H. (1985). Evaluation of morphological variability in Meloidogyne arenaria. Journal of Nematology 17, 445-459.

Cofcewicz, E.T., Carneiro, R.M.D.G., CastagnoneSereno, P. \& Quénéhervé, P. (2004). Enzyme phenotypes and genetic diversity of root-knot nematodes parasitising Musa in Brazil. Nematology 6, 85-95.

DAlmasso, A. \& Bergé, J.B. (1978). Molecular polymorphism and phylogenetic relationship in some Meloidogyne spp.: Application to taxonomy of Meloidogyne. Journal of Nematology 10, 323-332.

De Ley, I.T., De Ley, P., Vierstraete, A., Karssen, G., Moens, M. \& Vanfleteren, J. (2002). Phylogenetic analyses of Meloidogyne small subunit rDNA. Journal of Nematology 34, 319-327.

Dickson, D.W., Huisingh, D. \& SAsser, J.N. (1971). Dehydrogenases, acid and alkaline phosphatases, and esterases for chemotaxonomy of selected Meloidogyne, Ditylenchus, 
Heterodera, and Aphelenchus spp. Journal of Nematology 3, $1-16$.

EISENBACK, J.D. \& TRIANTAPHYLLOU, H.H. (1991). Rootknot nematode: Meloidogyne sp. and races. In: Nickle, W.R. (Ed.), Manual of agricultural nematology. New York, USA, Marcel Dekker, pp. 191-274.

Esbenshade, P.R. \& Triantaphyllou, A.C. (1985). Use of enzyme phenotypes for identification of Meloidogyne species. Journal of Nematology 17, 6-20.

Esbenshade, P.R. \& Triantaphyllou, A.C. (1987). Enzymatic relationship and evolution in the genus Meloidogyne (Nematoda: Tylenchida). Journal of Nematology 19, 8-18.

Fitch, D.H.A., Bugaj-Gaweda, B. \& Emmons, S.W. (1995). 18S ribosomal RNA gene phylogeny for some Rhabditidae related to Caenorhabditis. Molecular Biology and Evolution 12, 346-358.

HaNdoo, Z., NycZePIR, A.P., EsmenJaud, D., VAN DER Beek, J.G., Castagnone-Sereno, P., Carta, L.K., SkAntar, A.M. \& Higgins, J.A. (2004). Morphological, molecular and differential-host characterization of Meloidogyne floridensis $\mathrm{n}$. sp. (Nematoda: Meloidogynidae), a rootknot nematode parasitizing peach in Florida. Journal of $\mathrm{Ne}$ matology 36, 20-25.

Hasegawa, M., Kishino, H. \& Yano, T.-A. (1985). Dating of the human-ape splitting by a molecular clock of mitochondrial DNA. Journal of Molecular Evolution 22, 160-174.

Hernandez, A. (1997). Étude de la variabilité intra et interspécifique des nématodes du genre Meloidogyne parasites des caféiers en Amérique Centrale. Thèse de Doctorat, Académie de Montpellier II Science et Techniques du Languedoc, Montpellier, France, 98 pp.

Hugall, A.C., Stanton, J. \& Moritz, C. (1997). Evolution of the AT-rich mitochondrial DNA of the root knot nematode, Meloidogyne hapla. Molecular Biology and Evolution 14, 40-48.

JEPSON, S.B. (1987). Identification of root-knot nematodes (Meloidogyne species). Wallingford, UK, CABI Publishing, $265 \mathrm{pp}$.

JEYAPRAKASH, A. \& HoY, M.A. (2000). Long PCR improves Wolbachia DNA amplification: wsp sequences found in $76 \%$ of sixty-three arthropod species. Insect Molecular Biology 9, 393-405.

LiU, J., Berry, R.E. \& Moldenke, A.F. (1997). Phylogenetic relationships of entomopathogenic nematodes (Heterorhabditidae and Steinernematidae) inferred from partial 18S rRNA gene sequences. Journal of Invertebrate Pathology 69, 246-252.

PosADA, D. \& BuCKLEy, T.R. (2004). Model selection and model averaging in phylogenetics: Advantages of akaike in- formation criterion and bayesian approaches over likelihood ratio tests. Systematic Biology 53, 793-808.

PosadA, D. \& CRANDAll, K.A. (1998). MODELTEST: Testing the model of DNA substitution. Bioinformatics 14, 817-818.

POWERS, T.O. \& HARRIS, T.S. (1993). A polymerase chain reaction method for identification of five major Meloidogyne species. Journal of Nematology 25, 1-6.

RAmmah, A. \& Hirschmann, H. (1990). Meloidogyne morocciensis $\mathrm{n}$. sp. (Meloidogynidae) a root-knot nematode from Morocco. Journal of Nematology 22, 279-291.

Randig, O., Bongiovanni, M., CARneiro, R.M.D.G. \& Castagnone-Sereno, P. (2002). Genetic diversity of rootknot nematodes from Brazil and development of SCAR marker specific for the coffee-damaging species. Genome 45, 862-870.

SAITOU, N. \& NeI, M. (1987). The neighbor-joining method: A new method for reconstructing phylogenetic trees. Molecular Biology and Evolution 4, 406-425.

SCHOLL, E.H. \& BIRD, D.M. (2005). Resolving tylenchid evolutionary through multiple gene analysis derived from EST data. Molecular Phylogenetics and Evolution 36, 536545.

Steel, M., Huson, D., Lockhart, P.J. (2000). Invariable sites models and their use in phylogeny reconstruction. Systematic Biology 49, 225-232.

SWOFFORD, D.L. (2002). 'PAUP*: Phylogenetic analysis using parsimony (* and other methods)'. Sunderland, MA, USA, Sinauer Associates, Inc.

Thompson, J.D., Gibson, T.J., Plewniak, F., JeanmouGIN, F. \& Higgins, D.G. (1997). The Clustal X windows interface: Flexible strategies for multiple sequence alignment aided by quality analysis tools. Nucleic Acids Research 24, 4876-4882.

TriantaPhyllou, A.C. (1985). Cytogenetics, cytotaxonomy and phylogeny of root-knot nematodes. In: Barker, K.R., Carter, C.C. \& Sasser, J.N. (Eds). An advanced treatise on Meloidogyne. Vol. I. Biology and control. Raleigh, NC, USA, North Carolina State University Graphics, pp. 107-114.

Trudgill, D.L. \& BloK, V.C. (2001). Apomictic, polyphagous root-knot nematodes: Exceptionally successful and damaging biotrophic root pathogens. Annual Review of Phytopathology 39, 53-77.

VAN DER BEeK, J.G., FolKertsma, R., ZiJlstra, C., VAN Koert, P.H.G., PoleiJ, L. \& BAKKer, J. (1998). Genetic variation among parthenogenetic Meloidogyne species revealed by AFLPs and 2D-protein electrophoresis contrasted to morphology. Fundamental and Applied Nematology 21, 401-411. 